\title{
Maydanoz bakteriyel yaprak leke hastalığı (Pseudomonas syringae pv. apii) ile biyolojik mücadelede antagonist bakterilerin kullanım olanaklarının araştırılması
}

Investigation on the possible use of antagonistic bacteria in biological control of parsley bacterial leaf spot disease (Pseudomonas syringae pv. apii)

\author{
Resul VARHAN ${ }^{1 \mathscr{O}}$ (iD), i. Adem BOZKURT ${ }^{1}$
}

${ }^{1}$ Hatay Mustafa Kemal Üniversitesi, Ziraat Fakültesi, Bitki Koruma Bölümü, Antakya-Hatay, Türkiye.

MAKALE BILGISI / ARTICLE INFO

\section{Makale tarihçesi / Article history:}

DOI: $10.37908 /$ mkutbd.917150

Geliş tarihi /Received:16.04.2021

Kabul tarihi/Accepted:24.08.2021

\section{Keywords:}

Parsley, bacterial leaf spot, Pseudomonas syringae pv. apii, biological control, Bacillus simplex.

Corresponding author: i. Adem BOZKURT

凶: iabozkurt@mku.edu.tr

\author{
ÖZET / ABSTRACT
}

Atıf / Citation: Varhan, R, Bozkurt, IA (2021) Maydanoz bakteriyel yaprak leke hastalığı (Pseudomonas syringae pv. apii) ile biyolojik mücadelede antagonist bakterilerin kullanım olanaklarının araştırılması. MKU. Tar. Bil. Derg. 26(3) : 649-660. DOI: 10.37908/mkutbd.917150

\section{GíRiş}

Dünya genelinde 455 cins ve yaklaşık 3000'den fazla türü bulunan Apiaceae (Umbellifera) (Hickey ve King, 1997; Kızılaslan-Hançer, 2017) familyasında yer alan maydanoz (Petroselinum crispum (Mill.) Nym. Ex. A. W. Hill) sağlık, beslenme ve ekonomi açısından yaprağı yenen sebzeler arasında önemli bir yere sahiptir. Ekonomik anlamda ticari maydanoz üretimi gün geçtikçe artmaktadır. Anavatanı tam olarak bilinmemekle beraber Akdeniz Bölgesi olabileceği kabul edilmektedir (Ceylan, 1987). Türkiye'de 2019 yılında maydanoz üretimi 75.562 dekar 
alanda 92.954 ton olarak gerçekleşmiş olup, bu alanın 36.898 (\% 48.83) dekarı ve üretimin 50.544 (\% 54.38) tonu Hatay ilinde gerçekleştirilmiştir (Anonim, 2020).

Akdeniz Bölgesi ve özellikle Hatay ili için önemli bir sebze olan maydanoz bitkisinde verim ve kaliteyi olumsuz etkileyen birçok hastalık etmeni bulunmaktadır. Maydanoz köklerinde çürüklüğe neden olan Sclerotinia sclerotiorum (Lib) de Bary, Rhizoctonia solani Kühn, Fusarium spp, çökertene neden olan Pythium spp. ve Rhizoctonia spp, ve yeşil aksamda hastalık oluşturan Alternaria radicina Meier, Drech., and Eddy, Sclerotinia sclerotiorum, Cercospora spp. Septoria petroselini Desm ve Plasmopara petroselini önemli fungal hastalıklardır (Raid ve Roberts, 2004; Kurt ve Tok, 2006; Soylu ve ark., 2010; Kurt ve ark., 2017).

Maydanozlarda bakteriyel hastalıklar olarak ise Pseudomonas syringae pv. apii (Psa) ve Pseudomonas syringae pv coriandricola bildirilmektedir (Minchinton ve ark., 2006; Bull ve ark. 2011; Xu ve ark. 2013). Ülkemizde Maydanoz Bakteriyel Leke Hastalığına neden olan patojenin Pseudomonas syringae pv. apii olduğu ilk kez Bozkurt ve ark., (2016) tarafından bildirilmiştir. Her iki patojende maydanoz dışında Apiacea familyasından kişniş ve kerevizde de hastalık oluşturmaktadır (Pernezny ve ark., 1997; Cazorla ve ark., 2005; Cerkauskas, 2009; Bull ve ark., 2011; Gupta ve ark., 2013). Patojen ile enfekteli bitkilerde belirtiler genellikle benzer olup hastalığın ilk dönemlerinde enfeksiyon noktasında küçük, suyla ıslatılmış gibi ve yaprağın her iki tarafından görülebilen yaprak lekeleri şeklindedir. Bu lekeler genellikle yaprak damarları ile sınırlı olup hastalık ilerledikçe düzensiz, köşeli lekelere dönüşmekte ve lekelerin etrafında sarı bir hale meydana gelmektedir. Bu lekeler enfeksiyon ilerledikçe kurumakta ve hastalığın şiddetine göre maydanoz yapraklarının büyük bir kısmını veya tamamını kurutmaktadır (Bozkurt et al., 2016) (Şekil 1).

Hastalığın mücadelesinde genel olarak; enfekteli alanlardan temin edilen tohumların üretim materyali olarak kullanılmaması, tarla içerisinde oluşabilecek aşırı nemi azaltabilmek için yabancı ot kontrolü yapılması ve sık ekimden kaçınılması, ekim öncesi tohumların $50^{\circ} \mathrm{C}^{\prime}$ de 25 dakika bekletilerek tohum yüzeyindeki inokulum yoğunluğunun azaltılması, aşırı azotlu gübreleme yapılmaması, yaprak yüzeyinde uzun süre ıslaklık oluşturmayacak şekilde sulama yapılması gibi kültürel ve fiziksel mücadele yöntemleri önerilmektedir (Minchinton et al., 2006; Bozkurt ve Horuz, 2019). Hastalığın mücadelesinde önerilen herhangi bir kimyasal bulunmamaktadır.

Hastalık etmenine karşı bilinen etkili bir kimyasal mücadele olmaması ve antibiyotik kullanımının birçok ülkede yasak olması sebebiyle alternatif mücadele yöntemlerinin araştırılması kaçınılmazdır.

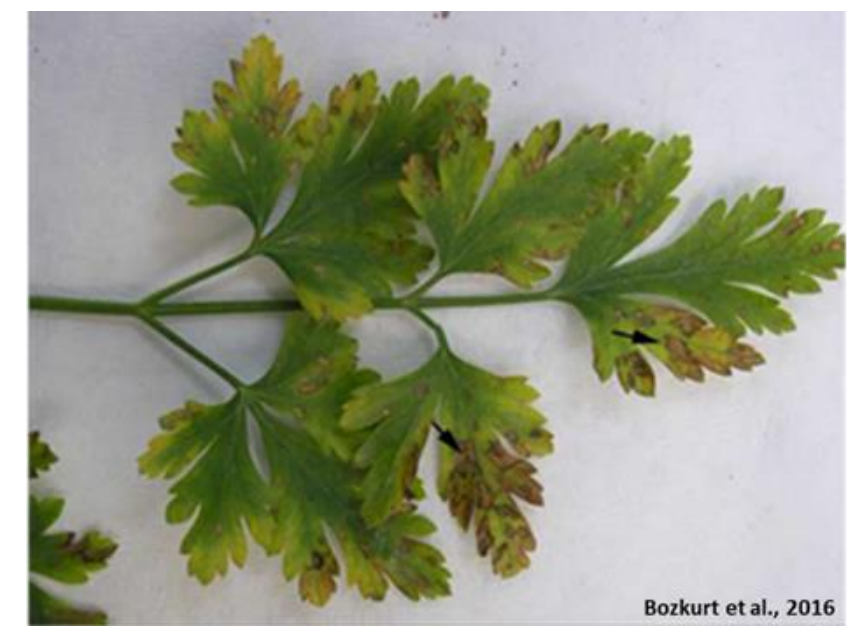

Şekil 1. Psa ile enfekteli maydanoz yapraklarında meydana gelen hastalık belirtileri (ok).

Figure 1. Disease symptoms on parsley leaves infected with Psa (arrow).

Bitki patojeni bakteriyel ve fungal hastalık etmenleri ile farklı ülkelerde olduğu kadar ülkemizde bitki uçucu yağ ve ana bileşenlerin kullanılması, kompost uygulamaları, bitki aktivatörlerinin kullanılmaları, nanoteknolojik antibakteriyel bileşiklerin geliştirilmesi şeklindeki yaklaşımlar gibi kimyasallara alternatif mücadele yöntemlerinin araştırılmasına son yıllarda ağırlık verilmiştir (Kara ve ark., 2020; Bozkurt ve ark., 2020; Şahin ve ark., 2021). Bitki bakteriyel hastalıklarla kimyasallara alternatif mücadele yöntemlerinden birisi de faydalı mikroorganizmaların kullanıldığı biyolojik mücadeledir. Biyolojik mücadele etmeni (BME) olarak en yaygın kullanılan mikroorganizmalardan biri olan bakteriler, bitkilerde bulundukları ve kolonize oldukları yerlere göre endofit ve epifit olarak iki şekilde isimlendirilmektedirler (Bozkurt ve Soylu, 2019; Duman ve Soylu, 2019). Epifit bakteriler bitkilerin çiçek, yaprak, meyve ve sürgün gibi toprak üstü ve kök gibi toprak altı kısımlarında kolonize olabilen ve bitkilere herhangi bir zararı olmayan bakteriler olarak tanımlanabilmektedir (Hallmann ve ark., 1998). Endofit bakterilerin farklı birçok tanımı olmakla beraber yaygın olarak; bitki dokularında kolonize olabilen ve herhangi bir simptoma ve bitkide zarara neden olmayan bakteriler olarak tanımlanmaktadır (Holliday, 1989; Schulz ve Boyle, 2006; Sülü ve ark., 2016).

Bu çalışma ile Maydanoz Bakteriyel Yaprak Leke Hastalığının sağlıklı maydanoz köklerinden izole edilen biyolojik mücadele etmeni (BME) bakteriler ile biyolojik mücadele olanakları in vitro ve in vivo koşullarda 
araştırılmıştır. Literatür taramalarında bu hastalığa karşı daha önceden yapılmış herhangi bir biyolojik mücadele çalışmasına rastlanılmamış olup, bu çalışma bir ilk niteliğindedir.

\section{MATERYAL ve YÖNTEM}

Çalışmada, test bitkisi olarak D'Giant Italiana maydanoz çeşidi kullanılmıştır. Test patojeni olarak Hatay Mustafa Kemal Üniversitesi Ziraat Fakültesi Bitki Koruma Bölümü bakteriyoloji laboratuvarı kültür koleksiyonunda bulunan Maydanoz Bakteriyel Yaprak Leke Hastalığı etmeni Pseudomonas syringae pv. apii PM-16 (Bozkurt ve ark., 2016) izolatı kullanılmıştır.

\section{Sağlıklı maydanoz köklerinden aday antagonist bakterilerin izolasyonu ve tanısı}

Survey çalışmaları Hatay ili ve ilçelerinde maydanoz üretimi yapılan alanlarda gerçekleştirilmiştir. Bakteriler sağlıklı maydanoz bitkilerinin köklerinden izole edilmiştir. Alınan kök örneklerinden $10 \mathrm{gr}$ tartılarak $90 \mathrm{ml}$ $0.05 \mathrm{mM} \mathrm{MgCl} 2$ tampon çözeltisi içerisinde $30 \mathrm{dk}$. çalkalayıcıda tutulduktan sonra süspansiyondan $100 \mu \mathrm{l}$ alınarak King $B(K B)$ besiyeri içeren petrilere bagetle yayılıp $24 \pm 2{ }^{\circ} C^{\prime}$ ye ayarlı inkübatörlere yerleştirilmiştir. Inkübasyondan 48 saat sonra petride gelişen koloniler saflaştırılarak UV ışık altında (366 nm) floresans pigment oluşturmalarına ve potasyum hidroksit $(\mathrm{KOH})$ testi ile gram reaksiyonlarına göre gruplandırılmıştır. Saflaştırılan bakteriler Nutrient Gliserol Agar (NGA) besiyerine ekilerek $+4{ }^{\circ} \mathrm{C}^{\prime}$ de saklanmıştır. Bakteri izolatlarının tanısı Matriks ile desteklenmiş lazer desorpsiyon/iyonizasyon uçuş zamanı kütle spektrometresi (Matrix-Assisted Laser Desorption Ionization-Time of Flight Mass Spectrometry) (MALDITOF-MS) ile Duman ve Soylu (2019) tarafından bildirilen yönteme göre yapılmıştır.

\section{Aday antagonist bakteri ile tütünde aşırı duyarlılık (HR) ve patateste yumuşak çürüklük testi}

Tütünde aşırı duyarlılık testi ve patates dilimlerinde yumuşak çürüklük testi aday antagonist bakteri izolatlarının bitki patojeni olup olmadığını belirlemek amacıyla yapılmıştır. HR testinde NA besi yerinde 24-48 saat geliştirilen aday antagonist bakteri kültürlerinden $10^{8}$ hücre $\mathrm{ml}^{-1} \quad(\mathrm{OD}=0.13)$ yoğunlukta hazırlanan süspansiyonlar steril enjektör yardımıyla tütün yaprağının damar aralarına enjekte edilmiştir. Pozitif kontrol olarak Psa izolatı negatif kontrol olarak ise yapraklara steril saf su inokule edilmiştir. Inokulasyondan 2 gün sonra inokulasyon noktasında doku çökmelerine ve nekrotik alanlara neden olan izolatlar HR (+) olarak kabul edilmiştir.
Yumuşak çürüklük testi için tütün HR negatif çıkan aday BME bakteri izolatları ile patates dilimlerinde yumuşak çürüklük testleri yapılmıştır. Patatesler dezenfekte edilmek amacıyla \%3'lük $\mathrm{NaOCl}$ 'de $1 \mathrm{dk}$. bekletilmiş, kabukları soyulduktan sonra \%70 alkol ile dezenfekte edilmiş ve alevde steril edilmiş bıçak ile ikiye ayırdıktan sonra $1 \mathrm{~cm}$. eninde dilimlenmiştir. İçinde steril ıslak filtre kağıdı bulunan steril petrilere patates dilimleri yerleştirilmiştir. Steril kürdan yardımıyla patates dilimleri üzerine bakteri izolatları inoküle edilmiştir (Şekil 3). Bakteri izolatları ile bulaştırılmış patates dilimlerinin bulunduğu petriler $25 \pm 1^{\circ} \mathrm{C}$ 'de inkübasyona bırakılmıştır. Inokulasyondan 1 gün sonra bakteri izolatlarının inoküle edildiği noktada yumuşama görülmesi pozitif olarak değerlendirilmiştir (Lelliot ve Stead, 1987). Pozitif kontrol bakterisi olarak Hatay Mustafa Kemal Üniversitesi Ziraat Fakültesi Bitki Koruma Bölümü bakteriyoloji laboratuarı kültür koleksiyonunda tanılanmış olan Pectobacterium caratovorum subs. caratovorum $(P C c)$ izolatı kullanıımıştır.

\section{Antagonist bakterilerin In vitro biyokontrol ve bitki gelişimini teşvik etme mekanizmalarının belirlenmesine yönelik çalışmalar \\ Antibiyosis testi}

Aday antagonist bakteri izolatlarının 24 saatlik kültüründen KB besi yeri içeren $9 \mathrm{~cm}$ çaplı petrilere birbirinden eşit uzaklıkta olmak üzere, 4 noktaya ekim yapılmıştır ve $25 \pm 1{ }^{\circ} \mathrm{C}^{\prime}$ de 48 saat inkübasyona bırakılmıştır. İnkübasyon sonrası gelişen bakteri kolonileri üzerine 24 saatlik Psa kültüründen hazırlanan patojen süspansiyonu $\left(10^{8}\right.$ hücre $\left.\mathrm{ml}^{-1}\right)$ pülverize edilmiştir. Petriler $25 \pm 1{ }^{\circ} \mathrm{C}^{\prime}$ de 48 saat inkübasyona bırakılmış ve 48 saat sonunda KB besi yerinde patojen gelişiminin engellenmesi sonucu oluşan engelleme bölgelerinin çapının bakteri kolonisinin çapına bölünmesi ile A-indeks değerleri hesaplanmıştır (Ullah ve ark., 2017). A-index = engelleme bölgesi çapı $(\mathrm{mm}) /$ bakteri koloni çapı $(\mathrm{mm})$

\section{Siderofor üretiminin belirlenmesi}

Hem bitki gelişimini teşvik edici etki hem de biyokontrol aktivitesi için önemli bir belirleyici olan siderofor üretimi Blue-CAS Agar besi yerinde Schwyn ve Neilands, 1997'ye göre belirlenmiştir. Siderofor etkinin varlı̆̆ını belirlemek için 2 günlük taze kültürden steril kürdan yardımıyla test edilecek bakteriden alınan inokulum, CAS agar ortamı bulunan $9 \mathrm{~cm}$. çaplı petrilere birbirinden eşit uzaklıkta 3 noktaya ekim yapılmış ve petriler $25 \pm 1^{\circ} \mathrm{C}^{\prime}$ de 7 gün inkübasyona bırakılmıştır. Antagonist bakteriler tarafından siderofor üretimine bağlı olarak oluşan sarıturuncu zonlar ve bakteri kolonisinin çapları ölçülmüştür. 
Meydana gelen zon çapları ve bakteri kolonisi çapları her izolat için siderofor çözünürlük indeksi (S-indeks) formülüne göre hesaplanarak ölçülmüştür (Ullah ve ark., 2017). Deneme 2 kez tekrarlanmıştır. S-index = sarıturuncu alanın çapı $(\mathrm{mm})$ / bakteri koloni çapı ( $\mathrm{mm}$ )

\section{Fosfor çözme potansiyellerinin belirlenmesi}

Aday bakteri izolatlarının fosfatı çözme etkinliği, trikalsiyum fosfat içeren Pikovskaya Agar (PVK) besi yeri içeren petrilerde belirlenmiştir (Kumar ve ark., 2012). Pikovskaya (PVK) agar içeren petrilere aday bakteri izolatları nokta ekim ile inokule edilmiş ve $25 \pm 1{ }^{\circ} \mathrm{C}^{\prime}$ de 7 gün inkübasyona bırakılmıştır. İnkübasyon sonrası bakteri kolonilerini etrafında fosforun çözülmesine bağlı olarak oluşan şeffaf zonun ve bakteri kolonisinin çapları ölçülerek F-indeks değerleri hesaplanmıştır (Ullah ve ark., 2017). F-index: erime bölgesinin çapı ( $\mathrm{mm}$ ) / bakteri koloni çapı (mm)

\section{Indol Asetik Asit (IAA) üretiminin belirlenmesi}

Aday bakteri izolatlarının IAA üretme potansiyelleri Ltryphtophan'nın varlığında Salkowski yöntemi kullanılmak suretiyle belirlenmiştir (Glickman ve Dessaux., 1995). IAA üretimi spektrofotometrik olarak UV-vis spektrofotometre (Perkin Elmer, Lamda 25, USA) ile belirlenmiştir. Örnekler $535 \mathrm{~nm}$ dalga boyunda okunarak absorbans değerleri saptanmıştır. Elde edilen absorbans değerleri saf IAA (Merck, Darmstadt, Germany) çözeltisi ile hazırlanan IAA konsantrasyon standart eğrisiyle karşılaştırılmak suretiyle (Aktan ve Soylu, 2020) aday bakteri izolatlarının IAA üretim miktarları $\mu \mathrm{g} / \mathrm{ml}$ olarak belirlenmiştir.

\section{Proteaz enzimi üretimi}

Aday antagonist bakteri izolatlarının proteaz enzimi üretme potansiyelleri, içerisinde $\% 2$ yağı alınmış süt tozu (Skimmed Milk Powder, Merck, Darmstad, Germany) bulunan LB (SMLBA) besi yerinde Perneel ve ark., (2007) tarafından bildirilen yönteme göre belirlenmiştir. SMLBA besi yerinde protez üretimine bağlı olarak bakteri kolonileri etrafında oluşan şeffaf bölgelerin ve bakteri kolonilerinin çapı ölçülerek Pro-indeks değerleri hesaplanmıştır (Ullah ve ark., 2017). Pro-index: erime bölgesinin çapı $(\mathrm{mm})$ / bakteri koloni çapı $(\mathrm{mm})$

\section{Aday antagonist bakteri izolatlarının in vivo saksı testleri ile biyokontrol etkinliklerinin belirlenmesi}

Saksı testlerinde aday antagonist bakteriler patosisteme a) Tohum uygulaması, b) Yaprak uygulaması c) Tohum+Yaprak uygulaması şeklinde uygulanmıştır. Deneme Hatay Mustafa Kemal Üniversitesi, Ziraat Fakültesi, Bitki Koruma Bölümü'nde bulunan gündüz ortalama $26.5 \pm 2^{\circ} \mathrm{C}$ ve gece $21 \pm 2^{\circ} \mathrm{C}$ sıcaklığa ve yaklaşık \%70-80 bağıl neme sahip ait cam serada yürütülmüştür. Denemede her izolat için 5 saksı kullanılmış ve deneme 2 kez yinelenmiştir.

KB besiyerinde gelişen 2 günlük antagonist bakteriler 5 $\mathrm{ml} \% 1^{\prime}$ lik Carboxy Methyl Cellulose (CMC) ile süspanse edilmiştir. Bu süspansiyon içerisine tohum uygulaması ve tohum+yaprak uygulamasına tabi olan maydanoz tohumları aktarılıp ( her uygulama için 50 tohum / $5 \mathrm{ml}$ CMC) 120 rpm'de $30 \mathrm{dk}$. çalkalanarak tohumların bakteri ile kaplanması sağlanmıştır (Callan ve ark., 1997). Muamele edilmiş tohumların saksılara ekimi yapılmıştır. Tohumların çimlenmesinden yaklaşık 2 hafta sonra (3-5 geçek yapraklı dönemde) yaprak ve yaprak+tohum uygulamasına tabi olan maydanoz bitkilerine KB besi yerinde geliştirilen 2 günlük antagonist bakteriler $\left(10^{8}\right.$ hücre $\mathrm{ml}^{-1}$ ) tüm yeşil aksamlarını kaplayacak şekilde pülverize edilmiştir. İnokulasyondan 1 gün sonra tohum uygulaması, yaprak uygulaması ve tohum+yaprak uygulamasına tabi olan maydanoz bitkilerinin KB besi yerinde geliştirilen 2 günlük patojen bakteri $\left(10^{8}\right.$ hücre $\mathrm{ml}^{-1}$ ) yine aynı şekilde pülverize edilmiştir. Kontrol (+) uygulamasında hiçbir muamele görmemiş tohumlardan elde edilen bitkilere patojen bakteri $\left(10^{8}\right.$ hücre $\left.\mathrm{ml}^{-1}\right)$ pülverize edilmiştir. Oluşan hastalık belirtileri patojen inokulasyonundan 14 gün sonra 0-4 skalasına göre değerlendirilmiş ve Tawsend Heuberger* formülü ile \% hastalık şiddeti belirlenmiştir.

\section{0-4 skalası}

0 - Yapraklarda nekrotik leke yok

1 - Yapraklarda 1-2 nekrotik leke

2 - Yapraklarda 3-5 nekrotik leke

3 - Yapraklarda 5 ve üzeri nekrotik leke

4 - Yapraklarda birleşik nekrotik leke

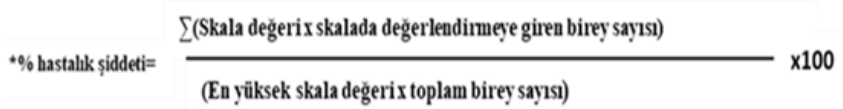

\section{Deneme deseni ve istatistik analizler}

Denemeler tesadüf parselleri deneme desenine göre kurulmuş olup, istatistik analizler SPSS istatistik programı (SPSS Statistics 17.0) kullanılarak tek yönlü ANOVA ile varyans analizi yapılmış ve izolatlar arasındaki farklılık Duncan Çoklu Karşılaştırma testi ile belirlenmiştir $(P \leq 0.05)$. 


\section{BULGULAR ve TARTIŞMA}

\section{Aday antagonist bakterilerin izolasyonu ve tanısı}

İzolasyon çalışmalarında morfolojik olarak birbirinden faklı olabileceği düşünülen 40 adet bakteri izole edilerek saflaştırımıştır. İzole edilerek saflaştırılan bakteri izolatlarının tanısı MALDI-TOF ile yapılmıştır. Tanı sonuçlarına göre cins düzeyinde ilk sırayı 12 izolatla Pseudomonas alırken, bunu 8 izolatla Arthrobacter, 7 izolatla Bacillus, 3 izolatla Lactobacillus, 2 izolatla Microbacterium ve 1'er izolatla Acinetobacter, Aeromicrobium, Mycobacterium, Sphingobacterium, Sinomonas, Escheria, Pantoea ve Stenotrophomonas cinslerine dahil izolatlar izlemiştir.

\section{Tütünde aşırı duyarlılık (HR) ve patates yumuşak çürüklük testi}

Tütün yapraklarında aşırı duyarlılık tepkimesinin belirlenmesi testinde pozitif kontrolde tipik HR belirtileri meydana gelirken negatif kontrol ve antagonist adayı izolatların inokule edildiği alanlarda herhangi bir belirti meydana gelmemiştir (Şekil 2).

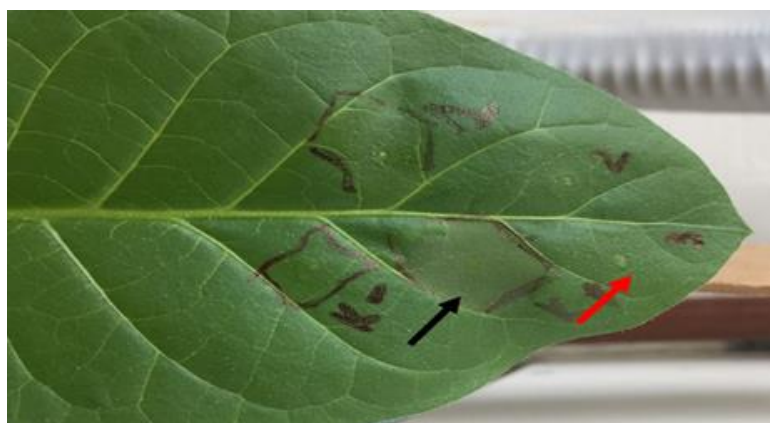

Şekil 2. Tütün HR testi sonucu meydana gelen HR pozitif (siyah ok) ve HR negatif (kırmızı ok) reaksiyonlar.

Figure 2. HR positive (black arrow) and HR negative (red arrow) reactions that occur as a result of the tobacco HR test.

Pektolitik enzim aktivitesinin belirlenmesi amacıyla yapılan patates dilimlerinde yumuşak çürüklük testinde değerlendirmeler inokulasyondan 1 gün sonra yapılmıştır. İnokulasyon noktasında meydana gelen yumuşama pozitif olarak kabul edilmiştir. Test sonucunda PCC inokule edilen pozitif kontrolde yumuşama meydana gelirken antagonist adayı bakterilerin inokule edildiği alanlarda ve negatif kontrol uygulamasında yumuşama meydana gelmemiştir (Şekil $3)$.
Aday antagonist bakteri izolatlarının antibiyosis testi ile ön eleme çalışmaları

Antagonistik etkinin belirlenmesinde 11 bakteriyel izolat antagonistik etki göstermez iken, 29 izolat ise patojen gelişimini engellemede farklı oranlarda antagonistik etki göstermiştir.

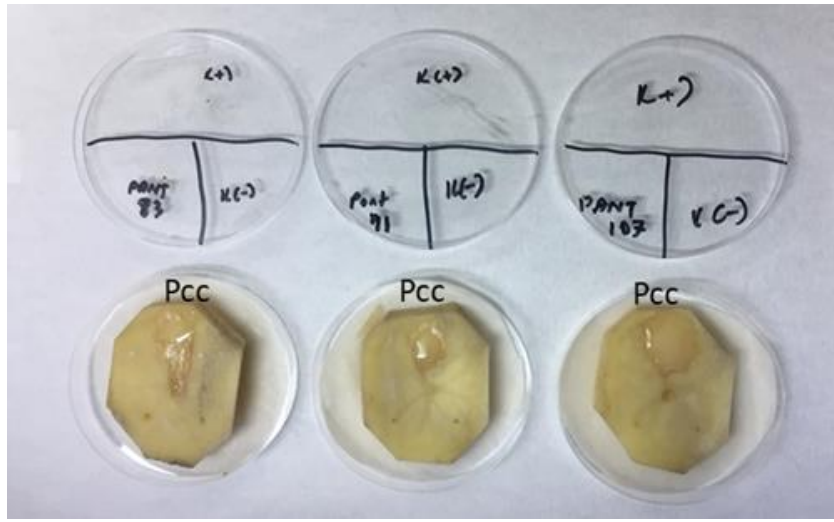

Şekil 3. Yumuşak çürüklük testinde pozitif kontrol $(\mathrm{K}+)$, aday antagonist bakteriler ve negatif kontrol $(\mathrm{K}-$ ) uygulamalarında meydana gelen belirtiler.

Figure 3. Positive control $(K+)$, candidate antagonist bacteria and negative control $(K-)$ symptoms in potato soft rot test.

Antibiyosis testinde en yüksek A-indeks değeri Pseudomonas thivervalensis PANT107 (5.08) izolatında belirlenmiş olup bunu Pseudomonas brassicacearum PANT83 (4.17) ve Bacillus simplex PANT91 (2.94) izolatı izlemiştir (Şekil 4, Çizelge 1). İstatistik analiz sonuçları değerlendirildiğinde ise Pseudomonas thivervalensis PANT107 ve Pseudomonas brassicacearum PANT83 izoları diğer tüm uygulamalardan farklı grupta yer almıştır fakat bu iki izolat arasında duncan çoklu testine göre $p=0.05$ aralığında fark olmadığı belirlenmiştir. Bir diğer izolat olan Bacillus simplex PANT91 izolatı ise Pseudomonas kiloensis PANT63 (1.67), Bacillus simplex PANT64 (1.63), Pseudomonas brassicacearum PANT710 (2.05) ve Pseudomonas brassicacearum PANT87 (1.78) izolatları ile Duncan Çoklu Karşılaştırma testine göre $p=0.05$ aralığında aynı grupta yer almış olup, istatistiki olarak aralarında bir fark belirlenmemiştir. 


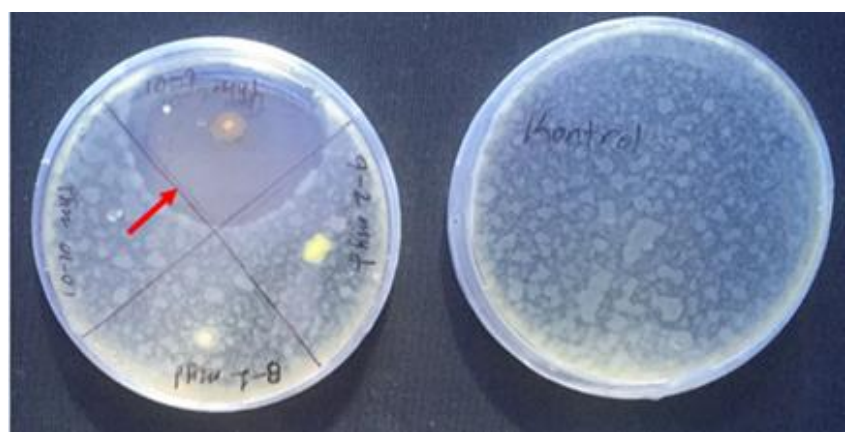

Şekil 4. Antagonist bakteri izolatlarının patojen gelişimini engellemesi sonucu oluşan engelleme bölgeleri (ok).

Figure 4. Inhibition zones formed as a result of antagonist bacteria isolates inhibiting the growth of pathogenic bacteria (arrow).

Pseudomonas thivervalensis ve Pseudomonas brassicacearum ilk defa Arabidopsis ve kanola bitkilerinin rizosferinden izole edilmişlerdir (Achouak ve ark., 2000). Yapılan bazı çalışmalarda $P$. thivervalensis ve $P$. brassicacearum gibi bazı Pseudomonas türlerinin pyoluteorin ürettiği belirlenmiştir. Pyoluteorin doğal bir antibiyotik olup antimikobiyal ve herbisidal etki gösterebilmektedir (Ramette ve ark., 2011). Bakteriyel hastalıklara olan etkiye bakıldığında ise Pseudomonas brassicacearum J12 izolatının domateslerde bakteriyel solgunluk etmeni Ralstonia solanacearum'un gelişimini etkili bir şekilde inhibe ettiği ve sera denemelerinde hastalık gelişimini \%45 oranında baskıladığı saptanmıştır (Zhou ve ark., 2012).

Bir diğer etkili izolat olan Bacillus simplex ise birçok fungal ve bakteriyel bitki patojenine karşı etkili olup biyolojik mücadele çalışmalarında yaygın olarak kullanılan bir bakteri türüdür (Krzyzanowska ve ark., 2012; Campos ve ark., 2010; Schwartz ve ark., 2013; Soylu ve ark., 2020; Atay ve ark., 2020; Kara ve ark., 2020). Yakın zamanda yapılan Elma Kök Uru Hastalığı etmeni Rhizobium radiobacter'e karşı epifit ve endofit bakteri izolatlarının antagonistik potansiyellerinin araştırıldığı bir diğer çalışmamızda Pseudomonas, Pantoea, Serratia ve Bacillus cinslerine dahil farklı türlere ait 12 izolat, ikili kültür testlerinin yapıldığı besi ortamı üzerinde patojene karşı ortalama 5.0-27.3 $\mathrm{mm}$ çapında arasında değişen engelleme zonları oluşturmuştur (Bozkurt ve Soylu, 2019).

\section{Siderofor üretiminin belirlenmesi}

Düşük molekül ağırlıklı bir element olan siderofor özellikle demirin sınırlı olduğu alanlarda birçok mikroorganizma ve bitki tarafından üretilmektedir (Schwyn and Neilands, 1987). Mikroorganizmalar tarafından üretilen sideroforlar bitkilerin demir alımını arttırarak bitki gelişimini teşvik ettiği için dolaylı olarak veya antimikrobiyal özelliklerinden dolayı ise doğrudan hastalıklarla mücadelede etkili olabilmektedir. Ayrıca demirin az olduğu alanlarda antagonist bakterilerin siderofor üretimi ile patojen mikroorganizmalar ile rekabete girmesi, doğrudan patojeni engellemese de dolaylı olarak patojen popülasyonunun azalmasına neden olabilmektedir.

CAS agar ortamına nokta ekim yapılan bakteri kolonilerinin etrafında oluşan sarı veya turuncu alanlar (Şekil 5) siderofor pozitif olarak kabul edilmiştir.

Siderofor üretim testinde en yüksek indeks değeri Pseudomonas thivervalensis PANT107 (2.86) izolatında belirlenirken bunu sırası ile antagonistik etkinlik sonuçlarına benzer Bacillus simplex PANT91 (2.31) ve Pseudomonas brassicacearum PANT83 (2.07) izolatları izlemiştir (Çizelge 1).

Istatistik analiz sonuçlarına göre Arthrobacter ilicis PANT59, Stenotrophomonas sp PANT82, Microbacterium phyllosphaerae PANT92 ve Bacillus megaterium PANT101 izolatları düşük oranlarda siderofor üretmekle beraber hiç siderofor üretmeyen Pseudomonas thivervalensis PANT88 izolatı ile aynı grupta yer almış olup istatistiki olarak önemsiz bulunmuştur.

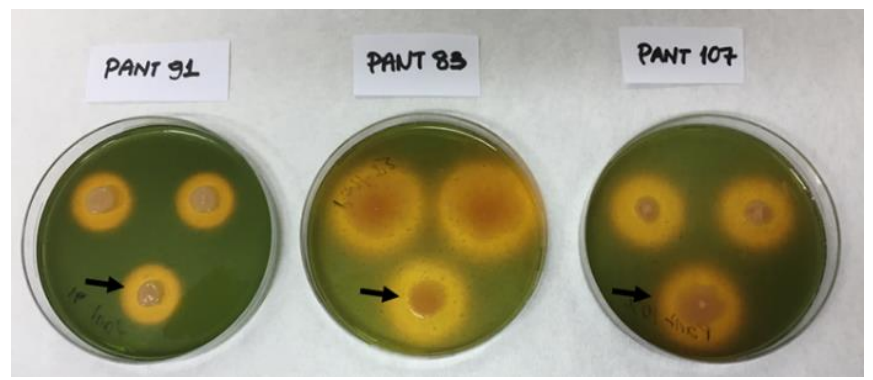

Şekil 5. CAS blue agar ortamında bakteri izolatlarının siderofor üretimleri sonucu oluşan sarı turuncu alanlar (ok).

Figure 5. Yellow-orange areas (arrow) formed as a result of siderophore production of bacterial isolates in CAS blue agar medium.

\section{Fosfor çözme potansiyellerinin belirlenmesi}

Fosfor çözünürlük testinde 17 bakteri izolatı etkisiz bulunmuş olup, 12 izolat ise 1.03-4.44 arasında değişen oranlarda fosfor çözme etkisi göstermiştir. En yüksek fosfor çözme indeksi Pseudomonas kilonensis PANT63 (4.44) nolu bakteri izolatında saptanırken bunu sırası ile Pseudomonas thivervalensis PANT107 (3.66), Pseudomonas brassicacearum PANT710 (3.55), Pseudomonas jessenii PANT34 (3.04) ve diğer izolatlar izlemiştir (Şekil 6, Çizelge 1). Bitkilerin sağlıklı bir şekilde büyüyüp gelişmesi için gerekli olan major elementlerden 
bir tanesi de fosfordur. Toprağa karışan fosfor kısa zamanda toprak parçacıklarının temas yüzeyleri ile reaksiyona girerek daha az çözünür ve daha az yarayışlı bileşikler haline dönüşür (Karaman, 2012). Topraktaki çözünebilir fosfor konsantrasyonu $1 \mathrm{ppm}$ veya daha az orandadır (Özyılmaz ve Benlioğlu, 2012). Toprakta bitki kökleriyle simbiyotik olarak yaşayan antagonist bakteriler, çözünemez durumundaki bu fosfor bileşiklerini çözerek bitkilerin yararlanabilecek forma dönüştürürler.

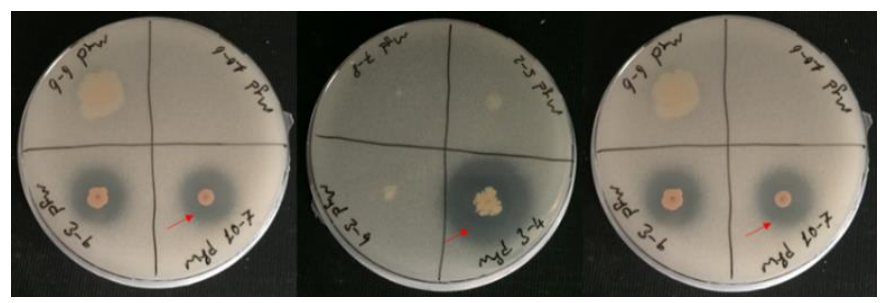

Şekil 6 Bakteri izolatlarının fosforu çözmeleri sonucu oluşan erime bölgeleri (ok).

Figure 6. Clearing zones formed as a result of bacterial isolates dissolving phosphorus (arrow).

\section{Indol asetik asit üretiminin belirlenmesi}

IAA üretiminin belirlenmesi testlerinde en yüksek IAA üretimi Arthrobacter oxydans PANT53 $(27.73 \mu \mathrm{g} / \mathrm{ml})$ izolatında saptanırken, bunu sırası ile Pseudomonas brassicacearum PANT83 $(20.40 \mu \mathrm{g} / \mathrm{ml})$ ve Bacillus simplex PANT91 $(19.88 \mu \mathrm{g} / \mathrm{ml})$ izolatları izlemiştir (Çizelge 1).

Bitkilerin büyüme ve gelişmesini düzenleyen en önemli faktörlerden bir tanesi de hormonlardır. Bu hormonların en bilineni de İndol-3- asetik asittir (IAA). IAA bitkide kök gelişimi, kök yüzey alanının genişlemesi, bitki besin elementlerin bitkiye alınması, hücre bölünmesi gibi birçok etkinliği bulunmaktadır (İmriz ve ark., 2014). Yapılan birçok çalışmada (Samuel ve Muthukkaroppan, 2011; İmriz ve ark., 2014) farklı türlere ait PGPR izolatlarının IAA ürettiği tespit edilmiştir.

Genel olarak toprak kökenli olup Artemisia sp, Chenopodium sp, Solanum nigrum, su sümbülü gibi yabancı otlardan, ceviz ve meşe gibi ağaçlardan izole edilen Arthrobacter cinsi bakterilerin yüksek düzeyde IAA ürettiği ve buğday, soya ve pirinç birçok bitkide bitki gelişimini arttırdığı yapılan birçok çalışmada bildirilmiştir (Soleimani ve ark. 2018, Xu ve ark., 2018; Li ve ark.,2018; Soylu ve ark., 2018; Khan ve ark., 2019). Yapılan bu çalışmasında da en yüksek IAA üretiminin Arthrobacter oxydans PANT53 izolatında saptanması Arthrobacter cinsine ait faklı türlerle yapılmış olan çalışmalar ile paralellik göstermektedir (Duman ve Soylu, 2019).

\section{Proteaz üretiminin belirlenmesi}

Proteaz testinde 8 izolat değişen oranlarda proteaz üretirken 21 izolatta ise proteaz üretimine rastlanmamıştır. En yüksek proteaz üretimi Pseudomonas brassicacearum PANT83 (2.51) izolatında belirlenirken bunu sırası ile Bacillus simplex PANT64 (2.12) Pseudomonas jessenii PANT34 (2.04) Pseudomonas thivervalensis PANT107 (2.00) ve diğerleri izlemiştir (Çizelge 1). Proteazlar, doğada bitkisel, hayvansal ve mikrobiyal kalıntıların dekompozisyonunda önemli rol oynamaktadırlar ve böylece besin döngüsünü sağlamakta ve ayrıca bitkilerin besinleri alabilmelerini sağlamaktadırlar (Anonim, 2019).

Çizelge 1. Aday antagonis bakteri izolatlarının in vitro biyokontrol etki mekanizmaları ve indeks değerleri

Table 1. In vitro biocontrol mechanisms and index values of candidate antagonist bacteria isolates

\begin{tabular}{llccccc}
\hline \multicolumn{1}{c}{ İolat } & \multicolumn{1}{c}{ Bakteri Tür İsimleri } & A-Indeks & S-indeks & F-indeks & $\begin{array}{c}\text { Pro- } \\
\text { indeks }\end{array}$ & IAA \\
\hline PANT15 & Pseudomonas flavescens & $1.21^{\mathrm{ab}}$ & $1.41^{\mathrm{bcd}}$ & $0,00^{\mathrm{a}}$ & $0.00^{\mathrm{a}}$ & $11.41^{\mathrm{d}-\mathrm{h}}$ \\
PANT21 & Acinetobacter pittii & $0.79^{\mathrm{ab}}$ & $1.23^{\mathrm{bcd}}$ & $0,00^{\mathrm{a}}$ & $0.00^{\mathrm{a}}$ & $3.26^{\mathrm{ab}}$ \\
PANT24 & Microbacterium lacticum & $0.84^{\mathrm{ab}}$ & $1.17^{\mathrm{bcd}}$ & $0,00^{\mathrm{a}}$ & $0.00^{\mathrm{a}}$ & $1.71^{\mathrm{ab}}$ \\
PANT34 & Pseudomonas jessenii & $0.80^{\mathrm{ab}}$ & $1.81^{\mathrm{b}-\mathrm{e}}$ & $3,04^{\mathrm{de}}$ & $2.04^{\mathrm{d}}$ & $12.41^{\mathrm{e}-\mathrm{i}}$ \\
PANT39 & Mycobacterium avium & $1.18^{\mathrm{ab}}$ & $1.28^{\mathrm{bcd}}$ & $2,00^{\mathrm{c}}$ & $1.57^{\mathrm{c}}$ & $9.74^{\mathrm{de}}$ \\
PANT44 & $* *$ S. multivorum & $1.31^{\mathrm{ab}}$ & $1.10^{\mathrm{bc}}$ & $0,00^{\mathrm{a}}$ & $0.00^{\mathrm{a}}$ & $14.61^{\mathrm{g}-\mathrm{j}}$ \\
PANT46 & Sinomonas atrocyanea & $1.39^{\mathrm{ab}}$ & $1.11^{\mathrm{bc}}$ & $0,00^{\mathrm{a}}$ & $0.00^{\mathrm{a}}$ & $5.02^{\mathrm{bc}}$ \\
PANT52 & Pseudomonas kilonensis & $1.46^{\mathrm{ab}}$ & $1.64^{\mathrm{bcd}}$ & $0,00^{\mathrm{a}}$ & $0.00^{\mathrm{a}}$ & $7.92^{\mathrm{cd}}$ \\
PANT53 & Arthrobacter oxydans & $1.14 \mathrm{ab}$ & $2.02^{\mathrm{cde}}$ & $0,00^{\mathrm{a}}$ & $0.00^{\mathrm{a}}$ & $27.73^{\mathrm{m}}$ \\
PANT59 & Arthrobacter ilicis & $1.33^{\mathrm{ab}}$ & $1.01^{\mathrm{abc}}$ & $1,35^{\mathrm{bc}}$ & $0.00^{\mathrm{a}}$ & $9.34^{\mathrm{de}}$ \\
PANT510 & $* * *$ A. polychromogenes & $1.34^{\mathrm{ab}}$ & $1.34^{\mathrm{bcd}}$ & $1,53^{\mathrm{bc}}$ & $0.00^{\mathrm{a}}$ & $10.44^{\mathrm{def}}$ \\
PANT63 & Pseudomonas kilonensis & $1.67^{\mathrm{bc}}$ & $1.59^{\mathrm{bcd}}$ & $4,44^{\mathrm{f}}$ & $0.73^{\mathrm{b}}$ & $0.41^{\mathrm{a}}$ \\
PANT64 & Bacillus simplex & $1.63^{\mathrm{bc}}$ & $1.31^{\mathrm{bcd}}$ & $1,03^{\mathrm{b}}$ & $2.12^{\mathrm{de}}$ & $14.60^{\mathrm{g}-\mathrm{j}}$ \\
PANT66 & Escherichia vulneris & $1.39^{\mathrm{ab}}$ & $1.92^{\mathrm{b}-\mathrm{e}}$ & $1,12^{\mathrm{b}}$ & $0.00^{\mathrm{a}}$ & $15.56^{\mathrm{jk}}$ \\
\hline
\end{tabular}


Çizelge 1 (devamı). Aday antagonis bakteri izolatlarının in vitro biyokontrol etki mekanizmaları ve indeks değerleri Table 1 (continued). In vitro biocontrol mechanisms and index values of candidate antagonist bacteria isolates

\begin{tabular}{llllllc}
\hline PANT72 & Lactobacillus gasseri & $1.00^{\mathrm{ab}}$ & $1.89^{\mathrm{b}-\mathrm{e}}$ & $0,00^{\mathrm{a}}$ & $0.00^{\mathrm{a}}$ & $18.56^{\mathrm{kl}}$ \\
PANT75 & Pantoea agglomerans & $0.79^{\mathrm{ab}}$ & $1.49^{\mathrm{bcd}}$ & $0,00^{\mathrm{a}}$ & $0.00^{\mathrm{a}}$ & $11.43^{\mathrm{d}-\mathrm{h}}$ \\
PANT78 & $* * * *$ P. brassicacearum & $1.24^{\mathrm{ab}}$ & $1.67^{\mathrm{bcd}}$ & $0,00^{\mathrm{a}}$ & $0.00^{\mathrm{a}}$ & $15.39^{\mathrm{h}-\mathrm{k}}$ \\
PANT710 & $* * * *$ P. brassicacearum & $2.05^{\mathrm{bc}}$ & $1.67^{\mathrm{bcd}}$ & $3,55^{\mathrm{de}}$ & $1.51^{\mathrm{c}}$ & $13.43^{\mathrm{e}-\mathrm{j}}$ \\
PANT82 & Stenotrophomonas $s p$ & $1.34^{\mathrm{ab}}$ & $0.81^{\mathrm{ab}}$ & $0,00^{\mathrm{a}}$ & $0.00^{\mathrm{a}}$ & $10.67^{\mathrm{d}-\mathrm{g}}$ \\
PANT83 & $* * * *$ P. brassicacearum & $4.17^{\mathrm{d}}$ & $2.07^{\mathrm{cde}}$ & $2,83^{\mathrm{d}}$ & $2.51^{\mathrm{e}}$ & $20.40^{1}$ \\
PANT87 & $* * * *$ P. brassicacearum & $1.78^{\mathrm{bc}}$ & $1.18^{\mathrm{bcd}}$ & $0,00^{\mathrm{a}}$ & $0.00^{\mathrm{a}}$ & $10.98^{\mathrm{d}-\mathrm{g}}$ \\
PANT88 & $* * * *$ P. thivervalensis & $1.34^{\mathrm{ab}}$ & $0.00^{\mathrm{a}}$ & $0,00^{\mathrm{a}}$ & $0.00^{\mathrm{a}}$ & $4.37^{\mathrm{bc}}$ \\
PANT91 & Bacillus simplex & $2.94^{\mathrm{c}}$ & $2.31^{\mathrm{de}}$ & $0,00^{\mathrm{a}}$ & $1.74^{\mathrm{cd}}$ & $19.88^{\mathrm{l}}$ \\
PANT92 & $* * * * *$ M. phyllosphaerae & $1.60^{\mathrm{b}}$ & $0.92^{\mathrm{abc}}$ & $0,00^{\mathrm{a}}$ & $0.00^{\mathrm{a}}$ & $4.30^{\mathrm{bc}}$ \\
PANT99 & Bacillus megaterium & $1.30^{\mathrm{ab}}$ & $1.40^{\mathrm{bcd}}$ & $1,12^{\mathrm{b}}$ & $0.00^{\mathrm{a}}$ & $14.40^{\mathrm{f}-\mathrm{j}}$ \\
PANT101 & Bacillus megaterium & $1.44^{\mathrm{ab}}$ & $0.88^{\mathrm{abc}}$ & $0,00^{\mathrm{a}}$ & $0.00^{\mathrm{a}}$ & $7.36^{\mathrm{cd}}$ \\
PANT102 & Bacillus simplex & $1.47^{\mathrm{ab}}$ & $1.41^{\mathrm{bcd}}$ & $0,00^{\mathrm{a}}$ & $0.00^{\mathrm{a}}$ & $10.01^{\mathrm{de}}$ \\
PANT106 & Bacillus megaterium & $1.32^{\mathrm{ab}}$ & $1.24^{\mathrm{bcd}}$ & $1,31^{\mathrm{bc}}$ & $0.00^{\mathrm{a}}$ & $9.38^{\mathrm{de}}$ \\
PANT107 & $* * * *$ P. thivervalensis & $5.08^{\mathrm{d}}$ & $2.86^{\mathrm{e}}$ & $3,66^{\mathrm{e}}$ & $2.00^{\mathrm{d}}$ & $17.04^{\mathrm{jkl}}$ \\
& Kontrol & $0.00^{\mathrm{a}}$ & $0.00^{\mathrm{a}}$ & $0.00^{\mathrm{a}}$ & $0.00^{\mathrm{a}}$ & $0.00^{\mathrm{a}}$ \\
\hline
\end{tabular}

* Her sütunda yer alan ortalama değerlerin yanındaki farklı harfler, izolatlar arasındaki farkın istatistiki olarak önemli olduğunu göstermektedir.

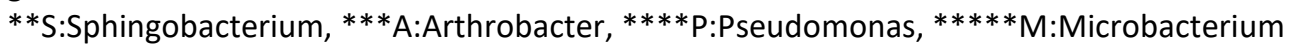

Aday antagonist bakterilerin in vivo saksı testleri ile biyokontrol özelliklerinin belirlenmesi

In vivo saksı testlerinde öncelikli olarak in vitro antibiyosis testlerinde daha sonra ise diğer testlerde etkili olarak saptanan Pseudomonas brassicacearum PANT 83, Bacillus simplex PANT91 ve Pseudomonas thivervalensis PANT107 izolatları kullanılmıştır. Patojen inokulasyonundan 14 gün sonra yapraklarda oluşan belirtiler 0-4 skalasına göre değerlendirilmiştir. Tüm muamelelerde meydana gelen hastalık şiddeti oranları \% olarak belirlenmiş, antagonist bakterilerin pozitif kontrole göre hastalı̆ı̆ engelleme oranları (\% etki) ayrıca belirlenmiştir (Çizelge 2.).

Çizelge 2. In vivo saksı testlerinde farklı antagonist bakteri uygulamalarının hastalık şiddeti üzerine etkileri Table 2. Effects of different antagonist bacteria applications on disease severity in in vivo pot tests

\begin{tabular}{|c|c|c|c|c|c|c|}
\hline İzolat & Tohum & & Tohur & & Yapra & \\
\hline & \%h.ş* & \%etki & \%h.ş & \%etki & \%h.ş & \%etki \\
\hline PANT83 & $5.10^{\mathrm{a}^{* *}}$ & 47.19 & $4.55^{\mathrm{a}}$ & 56.51 & $5.20^{\mathrm{a}}$ & 46.15 \\
\hline PANT91 & $4.10^{\mathrm{a}}$ & 57.54 & $4.05^{\mathrm{a}}$ & 58.56 & $4.25^{a}$ & 55.99 \\
\hline PANT107 & $5.40^{\mathrm{a}}$ & 43.26 & $5.31^{\mathrm{a}}$ & 44.08 & $8.05^{b}$ & 16.64 \\
\hline$K(+)$ & $9.66^{b}$ & --------.. & $9.66^{b}$ & |---------. & $9.66^{b}$ & -------. \\
\hline
\end{tabular}

*Hastalık Şiddeti

**Her sütunda yer alan ortalama değerlerin yanındaki farklı harfler, izolatlar arasındaki farkın istatistiki olarak önemli olduğunu göstermektedir.

Çizelge 2 incelendiğinde, aday antagonist bakteri izolatları ve patojen bakteri uygulanan bitkilerde hastalık şiddeti \%4.05-8.05 oranlarında tespit edilirken yalnız patojen inokule edilen bitkilerde hastalık şiddeti \%9,66 olarak belirlenmiştir. Uygulamalarda meydana gelen hastalık şiddetlerine göre yapılan istatistik analizlerde Pseudomonas thivervalensis PANT107 yaprak uygulaması pozitif kontrolle aynı grupta yer alırken diğer tüm uygulamalar pozitif kontrolden farklı bulunmuş ve ayrı grupta yer almıştır. Hastalığın engelleme oranlarına bakıldığında Bacillus simplex PANT91 izolatı tohum, tohum+yaprak ve yaprak uygulamalarında hastalık gelişimini \%57.54, \%58.56 ve \%55.99, Pseudomonas brassicacearum PANT83 izolatı \%47.19, \%56.51 ve $\% 46.15$, Pseudomonas thivervalensis PANT107 izolatı ise $\% 43.26, \% 44.08$ ve \%16.64 oranlarında engellemiştir. üç farklı uygulama karşılaştırıldığında ise genel olarak tohum+yaprak uygulamasının diğer uygulamalara göre daha etkili olduğu belirlenmiştir (Şekil 7).

Çalışmada elde edilen tüm sonuçlar birlikte 
değerlendirildiğinde özellikle in vitro antibiyosis ve diğer testlerin çoğunda etkili olarak saptanan Pseudomonas brassicacearum PANT83, Bacillus simplex PANT91 ve Pseudomonas thivervalensis PANT107 numaralı 3 aday bakteri izolatı in vivo saksı testlerinde kullanılmıştır. Bakteri izolatları patosisteme tohum, tohum+yaprak ve yaprak olarak 3 şekilde uygulanmıştır. Tüm izolatların her 3 uygulamada da hastalık gelişimini \%16-58 oranında engellediği saptanmıştır. Tohum, tohum+yaprak ve yaprak uygulamaları karşılaştırıldığında genel olarak tohum+yaprak uygulamalarının diğer uygulamalara göre daha etkili olduğu belirlenmiştir. Hastalığın engelleme

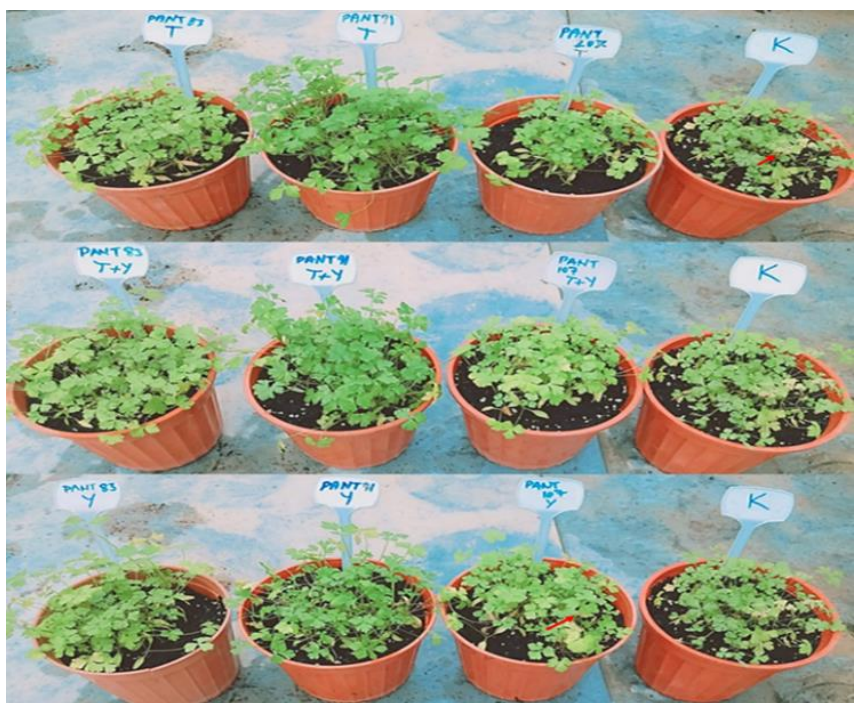

Şekil 7. Saksı denemeleri sonucunda farklı bakteri ve K (+) uygulamasında meydana gelen hastalık belirtileri.

Figure 7. Disease symptoms occurring in pot trials with different bacteria and $K(+)$ applications.

oranına bakıldığında tohum, tohum+yaprak ve yaprak uygulamalarında en iyi oranı Bacillus simplex PANT91 izolatı olduğu saptanmış, bunu sırasıyla Pseudomonas brassicacearum PANT83 ve Pseudomonas thivervalensis PANT107 izolatı izlemiştir.

Son yıllarda kimyasalların aşırı kullanımı sonucu toprak ve çevre kirliliği artmakta ve tarım alanları hızla azalmaktadır. Sürdürülebilir tarım için çevreyi ve toprağı kirleten kimyasalların kullanımı azaltılmalı ve kontrol altına alınmalıdır.

Yapılan bu çalışmada elde edilen sonuçlar maydanoz bakteriyel leke hastalığı etmenine $(P s a)$ karşı mücadelede antagonist bakteriler ile biyolojik mücadelenin etkili olabileceği tespit edilmiştir.

\section{ÖZET}

Amaç: Bu çalışmanın amacı, maydanoz köklerinden izole edilen epifit bakterilerin in vitro ve in vivo koşullarda Maydanoz Bakteriyel Yaprak Leke Hastalığı etmeni Pseudomonas syringae pv apii (Psa)' ye karşı biyolojik mücadele potansiyellerinin belirlenmesidir.

Yöntem ve Bulgular: Sağlıklı maydanoz bitkilerinin kök bölgelerinden 48 adet aday antagonist bakteri izolatı izole edilmiştir. Bakteri izolatlarının tanısı MALDI-TOF ile yapılmıştır. İole edilen ve tanısı yapılan 40 bakteri izolatının in vitro koşullarda hastalık etmenine karşı antagonistik etkilerinin yanı sıra siderofor, indol asetik asit (IAA), proteaz, amonyak üretimi ve fosfor çözme potansiyelleri gibi etki mekanizmaları belirlenmiştir. Antagonistik etkinin belirlendiği antibiyosis testinde en yüksek indeks değeri Pseudomonas thivervalensis PANT107 (5.08) izolatında belirlenmiş olup bunu Pseudomonas brassicacearum PANT83 (4.17) ve Bacillus simplex PANT91 (2.94) izolatı izlemiştir.

in vivo etkinlik denemelerinde bakteri izolatları farklı (tohum kaplama, tohum kaplama+yaprak püskürtme ve yaprak püskürtme uygulamaları) şekillerde uygulandıkları bitkilerde hastalık gelişimini \% 16-58 oranında engellemiş olup, en etkili izolatın. Bacillus simplex PANT91 olduğu belirlenmiştir. Uygulamalar karşılaştırıldığında genel olarak tohum+yaprak uygulamalarının hastalık çıkışını engelleme açısından diğer uygulamalara göre daha etkili olduğu belirlenmiştir.

Genel Yorum: Yapılan bu çalışmada elde edilen sonuçlar Maydanoz Bakteriyel Leke Hastalığı etmenine (Psa) karşı mücadelede antagonist bakteriler ile biyolojik mücadelenin etkili olabileceği tespit edilmiştir Çalışmanın Önemi ve Etkisi: Hastalık etmenine karşı bilinen etkili bir kimyasal mücadelesi olmaması ve antibiyotik kullanımının birçok ülkede yasak olması sebebiyle alternatif biyolojik mücadele yöntemleri araştırııması kaçınılmazdır. Yapılacak çalışmalar sonucunda bu izolatların maydanoz bakteriyel leke hastalığına karşı etkili olabileceği ve biyolojik mücadele elemanı olarak kullanılabileceği düşünülmektedir.

Anahtar Kelimeler: Maydanoz, bakteriyel yaprak lekesi, Pseudomonas syringae pv apii, biyolojik mücadele, Bacillus simplex.

\section{TEŞEKKÜR}

Bu çalışma Hatay Mustafa Kemal Üniversitesi Bilimsel Araştırma Projeleri Komisyonu Başkanlığı tarafından finansal olarak desteklenmiştir (Proje Numarası: MKU BAP-17.YL.023).

\section{ÇIKAR ÇATIŞMA BEYANI}

Makale yazarları aralarında herhangi bir çıkar çatışması 
olmadığını beyan ederler.

\section{ARAŞTIRMACILARIN KATKI ORANI BEYANI}

Yazarlar makaleye eşit oranda katkı sağlamış olduklarını beyan ederler.

\section{KAYNAKLAR}

Anonim

https://www.foodelphi.com/tag/proteaz/

(Erişim

Tarihi: 15 Ocak 2019).

Anonim

http://tuikapp.tuik.gov.tr/bitkiselapp/bitkisel.zul

(Erişim Tarihi: 8 Şubat 2020).

Achouak W, Sutra L,Heulin T, Meyer JM, Fromin N,

Degraeva S, Christen R, Gardan L (2000) Pseudomonas brassicacearum sp. nov. and Pseudomonas thivervalensis sp. Nov., two rootassociated bacteriai solated from Brassica napu and Arapidopsis thaliana. International Journal of Systematic and Evolutionary Microbiology 50: 9-18.

Aktan ZC, Soylu S (2020) Diyarbakır ilinde yetişen badem ağaçlarından endofit ve epifit bakteri türlerinin izolasyonu ve bitki gelişimini teşvik eden mekanizmalarının karakterizasyonu. KSU Tarım ve Doğa Derg. 23: 641-654.

Atay M, Kara M, Uysal A, Soylu S, Kurt Ş, Soylu EM (2020) In vitro antifungal activities of endophytic bacterial isolates against postharvest heart rot disease agent Alternaria alternata in pomegranate fruits. Acta Horticulturae 1289: 309-314.

Bozkurt IA (2009) Fasulye bakteriyel yanıklık hastalığına (Xanthomonas axonopodis pv. phaseoli) karşı antogonist bakterilerle mücadele olanakları. Doktora Tezi, Ege Üniversitesi Fen Bilimleri Ens., Bitki Koruma ABD, $152 \mathrm{~s}$.

Bozkurt IA, Horuz S, Aysan Y, Soylu S (2016) First report of bacterial leaf spot of parsley caused by Pseudomonas syringae pv. apii in Turkey. Journal of Phytopathology 3: 207-211.

Bozkurt IA, Soylu S (2019) Elma kök uru hastalığı etmeni Rhizobium radiobacter'e karşı epifit ve endofit bakteri izolatlarının antagonistik potansiyellerinin belirlenmesi. Tekirdağ Ziraat Fakültesi Dergisi 16: 348-361.

Bozkurt IA, Soylu S, Kara M, Soylu EM (2020) Chemical composition and antibacterial activity of essential oils isolated from medicinal plants against gall forming plant pathogenic bacterial disease agents. KSU Tarım ve Doğa Derg. 23: 1474-1482.

Bull CT, Clarke CR, Cai R, Vinatzer BA, Jardini TM, Koike ST (2011) Multilocus sequence typing of Pseudomonas syringae Sensu Lato confirms previously described genomospecies and permits rapid Identification of $P$. syringae pv. coriandricola and $P$. syringae pv. apii causing bacterial leaf spot on parsley. Phytopathology 101: 847-858.

Callan NW, Mathre DE, Miller JB, Vavrina CS (1997) Biological seed treatments: Factors involved in efficacy. Hort-Science 32: 179-183.

Campos VP, de Pinho S.C, Freire ES (2010) Volatiles produced by interacting microorganisms potentially useful for the control of plant pathogens. Ciênc. Agrotec. Lavras Rewiev. 34(3): 525-535.

Cazorla FM, Vazoquez MA, Rosales J, Arrebola E, Navarro J, Perez-Garcia A, de Vicente A (2005) First report of bacterial leaf spot (Pseudomonas syringae pv. coriandricola) of coriander in Spain. J. Phytopathology 153: 181-184.

Cerkauskas RF (2009) Bacterial leaf spot of cilantro (Coriandrum sativum) in Ontario. Can. J. Plant. Pathol. 31: 16-21.

Ceylan A (1987) Tıbbi Bitkiler II. Ege Üniversitesi, Ziraat Fakültesi yayınları. No:169, cilt:Il, 429s, İzmir.

Chung BS, Aslam Z, Kim SW, Kim GG, Kang HS, Ahn JW, Ryun Y (2008) A bacteria endophyte, Pseudomonas brassicacearum YC5480, isolated from root of Artemisia sp. producing antifungal and phytotoxic compound. Plant Pathol. J. 24(4): 461-468.

Duman K, Soylu S (2019) Characterization of plant growth-promoting traits and antagonistic potentials of endophytic bacteria from bean plants against Pseudomonas syringae pv. phaseolicola. Bitki Koruma Bülteni 59:59-69.

Glickman E, Dessaux Y (1995) A critical evaluation of the specificity of Salkowski reagent for indole compounds produced by phytopathogenic bacteria. Applied and Environmental Microbiology 61: 793-796.

Gupta M ,Bharat N, Chauhan A, Vikram A (2013) First report of bacterial leaf spot of coriander caused by Pseudomonas syringae pv. coriandricola in India. Plant Dis. 97(3): 418.

Hallmann J, Quadt HA, Rodrguez R, Kloepper JW (1998) Interactions between Meloidogyne incognita and endophytic bacteria in cottonand cucumber. Soil Biology and Biochemistry 30: 925-937.

Hickey M, King C (1997) Common Families of Flowering Plants. Cambridge University Press, Cambridge, United Kingdom.

Holliday P (1989) A dictionary of plant pathology. Cambridge University Press, No: 2: Cambridge.

İmriz G, Özdemir F, Topal I, Ercan B, Taş MN, Yakışır E, Okur O (2014) Bitkisel üretimde bitki gelişimini teşvik eden rizobakteri (PGPR)'ler ve etki mekanizmaları. Elektronik Mikrobiyoloji Dergisi 12(2): 1-19. 
Kara, M, Soylu S, Kurt Ş, Soylu EM, Uysal A (2020) Determination of antagonistic traits of bacterial isolates obtained from apricot against green fruit rot disease agent Sclerotinia sclerotiorum. Acta Horticulturae 1290: 135-142.

Kara M, Soylu S, Türkmen M, Kaya DA (2020) Determination and antifungal activities of laurel and fennel essential oils against fungal disease agents of cypress seedlings. Tekirdağ Ziraat Fakültesi Dergisi 17: 264-275.

Karaman MR (2012) Bitki besleme belemenin temel ilkeleri bitki besleme. 1066s, Ankara.

Khan MA, Ullah I, Waqas M, Hamayun M, Khan AL, Asaf S, Kang SM, Kim KM, Jan R, Lee IJ (2019) Halo-tolerant rhizospheric Arthrobacter woluwensis AK1 mitigates salt stress and induces physio-hormonal changes and expression of GmST1 and GmLAX3 in soybean. Symbiosis 77(1): 9-21.

Kızılaslan HÇ (2017) Apiaceae familyası meyve anatomisindeki "Vitta" terimi ve yerleşimleri. Avrasya Terim Dergisi 5(2): 19-24.

Krzyzanowska DM, Potrykus M, Golanowska M, Polonis K, Gwizdek-Wisniewska A, Lojkowska E, Jafra S (2012) Rhizosphere bacteria as potential biocontrol agents against soft rot caused by various Pectobacterium and Dıckeya spp. strains. Journal of Plant Pathology 94(2): 367-378.

Kumar P, Dubey RC, Maheshwari DK (2012) Bacillus strains isolated from rhizosphere showed plant growth promoting and antagonistic activity against phytopathogens. Microbiological Research 167: 493499.

Kurt S, Tok FM (2006) Influence of inoculum concentration, leaf age, temperature and duration of leaf wetness on Septoria blight of parsley. Crop Production 25(6): 556-551.

Kurt S, Uysal A, Kara M, Soylu S, Soylu EM (2017) First report of stem rot disease of parsley caused by Sclerotinia sclerotiorum in Turkey. Journal of Plant Pathology 99(1): 301.

Li M, Guo R, Yu F, Chen X, Zhao H, Li H, Wu J (2018) Indole-3-Acetic acid biosynthesis pathways in the plant-beneficial bacterium Arthrobacter pascens ZZ21. Int. J. Mol. Sci. 19(2): 443.

Loper JE, Gross H (2007) Genomic analysis of antifungal metabolite production by Pseudomonas fluorescens Pf-5. European Journal of Plant Pathology 119: 265278.

Minchinton E, Auer D, Martin H, Tesoriero L (2006) Bacterial leaf spot. Guide to common diseases and disorders of parsley. 9.

Özyılmaz Ö, Benlioğlu K (2012) Fosfat çözen bakterilerin pamuk bitkisinin gelişimine ve Verticillum solgunluğuna etkileri. Türk. Biyo. Müc. Derg. 3(1): 4762.

Pavlovic M, Konrad R, Iwobi AN, Sing A, Busch U, Huber I (2012) A dual approach employing MALDI-TOF MS and real-time PCR for fast species identification within the Enterobacter cloacae complex. FEMS Microbiology Letters 328: 46-53.

Perneel M, Heyrman J, Adiobo A, De Maeyer K, Raaijmakers LM, De Vos P, Höfte M (2007) Characterization of CMR5c and CMR12a, novel fluorescent Pseudomonas strains from the cocoyam rhizosphere with biocontrol activity. Journal of Applied Microbiology 103(4): 1007-20.

Pernezny K, Raid RN, Jones JB (1997) Bacterial leaf spot of cilntro in Florida. Diseases Notes 81(2): 232.

Raid R, Roberts P (2004) Plant diseases management guide. 3: 43.

Ramette A, Frapolli M, Fischer-Le Saux M, Gruffaz C, Meyer JM, Défago G, Sutra L, Moënne-Loccoz Y (2011) Pseudomonas protegens sp. nov widespreas plant protecting bacteria producing the biocontrol compounds 2,4 diacetylphloroglucinol and pyoluteorin. Systematic and Applied Microbiology 34(3): 180-188.

Ross IL, Alamı Y, Harvey PR, Achouak W, Ryder MH (2000) Genetic diversity and biological control activity of novel species of closely related pseudomonads Isolated from wheat field soils in south australia. Applied and Environmental Microbiology 66(4): 16091616.

Samuel S, Muthukkaruppan, SM (2011) Characterization of plant growth promoting rhizobacteria and fungi associated with rice, mangrove and effluent contaminated soil. Current Botany 2(3): 22-25.

Schulz B, Boyle C (2006) What are endopytes? (Schulz, B., Boyle, C., \& N., T., Editör). In: Microbial Root Endophytes. Springer-Verlang, No: 1-13, Berlin.

Schwartz AR, Ortiz I, Maymon M, Herbold CW, Fuiishige NN, Vijanderan JA, Villella W, Hanamoto K, Diener A, Sanders ER, DeMason DA, Hirsch AM (2013) Bacillus simplex-A little known pgpr with anti-fungal activityalters pea legume root architureand nodule morphology when coinoculated with Rhizobium leguminosarum by viciae. Argonomy 3(4): 595-620.

Schwyn B, Neilands J.B (1997) Universal chemical assay forthed etection and determination of siderophores. Anal. Biochem. 160: 46-56.

Soylu S, Soylu EM, Kurt S (2010) Downy mildew outbreak on parsley caused by Plasmopara petroselini in Turkey. Plant Pathology 59(4): 799.

Soylu S, Kara M, Üremiş I, Kurt Ş, Soylu EM, Uysal A 
(2018) Determination of plant growth promoting traits of bacterial endophytes isolated and identified from invasive plant water Hyacinth Eichhornia crassipes in Orontes river of Turkey. $1^{\text {st }}$ International Mediterranean Symposium, 01-03 November 2018, Mersin/Turkey. Volume 4: 65-78.

Soylu EM, Soylu S, Kara M, Kurt Ş (2020) Sebzelerde sorun olan önemli bitki fungal hastalık etmenlerine karşı vermikomposttan izole edilen mikrobiyomların in vitro antagonistik etkilerinin belirlenmesi. KSU Tarım ve Doğa Dergisi 23: 7-18.

Soleimani R, Alikhani HA; Towfighi H, Pourbabaei AA, Khavazi K (2018) Indole-3-acetic acid and 1aminocyclopropane-1-carboxylate deaminaseproducing bacteria alleviate sodium stress and promote wheat growth. Iranian Journal of Science and Technology Transaction A-Science 42(A3): 10371048.

Sülü SM, Bozkurt IA, Soylu S (2016) Bitki büyüme düzenleyici ve biyolojik mücadele etmeni olarak bakteriyel endofitler. MKÜ Ziraat Fakültesi Dergisi 21: 103-111.

Şahin B, Soylu S, Kara M, Türkmen M, Aydin R, Çetin H (2021) Superior antibacterial activity against seedborne plant bacterial disease agents and enhanced physical properties of novel green synthesized nanostructured $\mathrm{ZnO}$ using Thymbra spicata plant extract. Ceramics International 47: 341-350.
Ullah A, Musthag H, Fahad S, Shah A, Chaudhary HJ (2017) Plant growth promoting potential of bacterial endophytes in novel association with Olea ferruginea and Withania coagulans. Microbiology 86(1): 119127.

Wilson M, Campbell HL, Ji P, Jones JB, Cuppels DA (2002). Biological control of bacterial speck of tomato under field conditions at several locations in North America. Phytopathology 92: 1284-1292.

Xu X, Miller SA (2013) First report of bacterial spot of parsley caused by Pseudomonas syringae pv. coriandricola in Ohio. Plant Dis. 97(7): 988.

Xu XH, Xu M, Zhao QM, Xia Y, Chen C, Shen ZG (2018) Complete genome sequence of $\mathrm{cd}(\mathrm{II})$-resistant Arthrobacter sp PGP41, a Plant Growth-Promoting Bacterium with potential in microbe-assisted phytoremediation. Current Microbiology 75(9): 12311239.

Zhou TT, Chen D, Li CY, Sun Q, Liu F, Shen Q, Shen B (2012) Isolation and characterization of Pseudomonas brassicacearum $\mathrm{J12}$ as an antagonist against Ralstonia solanacearum an identification of its antimicrobial components. Microbiological Research 167(7): 388-394. 